\title{
Közösségi modellek az esélyegyenlőség szolgálatában
}

A tanulmány az információs és kommunikációs technológiák szerepét és hatását vizsgálja a gazdaság és a társadalom változásaiban. Rámutat, hogy az egyik legfontosabb jelenség az immaterializálódás, a hagyományosan materiális termékek és szolgáltatások „információs termékké” vagy „tudástermékké” válása. Ez a tény azonban a szerző állítása szerint egyre élesebb ellentétbe kerül a ma uralkodó termelési viszonyokkal. Az alapvetően kirekesztő piaci modell erősen korlátozza azokat a lehetőséget, amelyeket az elméletileg el nem fogyó tulajdonságú javak kínálnak. A közösségi alapú hozzáférés az oktatás, a kultúra, az egészség; a hivatali és a magánélet szinte minden területén megjelenő új termékekhez és szolgáltatásokhoz, illetve ezeknek a termékeknek és szolgáltatásoknak közösségi formákban történő előállítása sok-sok ember számára biztosíthat valódi esélyegyenlőséget a gyakorlatban is. Azt, hogy ez mennyire nem utópista elképzelés, hanem a mai valóság része, a szerző a „Koldus és királyfi” diafilmes (és egyéb) feldolgozásainak on-line és off-line hozzáférhetőségére felhozott szemléltető példákon keresztül mutatja be.

Kulcsszavak: közösségi modell, immaterializálódás, digitális termék, tudástermék, elektronikus szolgáltatás, szabad szoftver, Copyleft

\section{Szerzői információ:}

Ferge Sándor

Építốmérnök, informatikus. Számítógéppel segített tervezéssel (CAD, CAM), épületek és építmények szerkezetének számítógépes modellezésével és számítógéppel vezérelt megjelenítésével foglalkozott. Gazdasági vonalon pénzügyi, számviteli, készletgazdálkodási, gyártástervezési, termelésirányítási és projekttervezési informatikai feladatokat látott el, továbbá integrált ügyvitel-szervezési, vállalat- és intézményirányítási rendszereket tervezett és múködtetett. Átmenetileg egy nagyterületúhálózat (WAN) fejlesztési projekt programozójaként, valamint a számítástechnika oktatójaként is dolgozott. Az IHM köztisztviselójeként irányítója volt a Magyar Információs Társadalom Stratégiát kidolgozó szakértôi csoportnak, az ITKTB stratégiai albizottságának vezetôjeként a stratégiai tervezômunka és az információs társadalom jelenségeit monitorozó tevékenység koordinációját látta el. Publikációival hozzájárul ahhoz, hogy az információs társadalom fejlesztésének legfontosabb elemei minél szélesebb körben ismertté és jelentôségüknek megfelelô súlyú kérdéssé váljanak.

E-mail: ferge.sandor@gmail.com

Így hivatkozzon erre a cikkre:

Ferge Sándor. „Közösségi modellek az esélyegyenlőség szolgálatában”.

Információs Társadalom VI, 2. szám (2006): 39-47.

https://dx.doi.org/10.22503/inftars.VI.2006.2.5

A folyóiratban közölt müvek

a Creative Commons Nevezd meg! - Ne add el! - Így add tovább! 4.0

Nemzetközi Licenc feltételeinek megfelelően használhatók. 
Ferge Sándor

\section{Közösségi modellek \\ az esélyegyenlóség szolgálatában}

Az esélyegyenlőség - mint egyre aktuálisabb hívószó - napjaink társadalmának egyik legnagyobb és legfontosabb problémájára hívja fel a figyelmet. A hívószó mögött elsôsorban a szegénység kialakulása, mélyülése húzódik meg egyes leszakadó társadalmi csoportok esetében, akik számára egyre kisebb az esély a rossz élethelyzet megváltoztatására.

Azt, hogy mennyire fontos problémáról van szó, jól mutatja az is, hogy az idei (2005. évi) emelt szintû érettségi néhány tétele éppen ezzel a kérdéssel foglalkozott. Az éppen most felnốtté váló fiataloknak az egyik kérdésben fel kellett sorolniuk hatot a szegénység kialakuásának okai közül. A tananyag a felkészüléshez ennél több lehetséges okot is említ:

- a társadalmi egyenlótlenségek felerósödése,

- a munkanélküliség,

- az aluliskolázottság,

- a terïleti egyenlốtlenségek,

- bizonyos gazdasági ágak tönkremenetele,

- a megélhetési költségek növekedése stb.,

- a lakásfenntartási költségek növekedése,

- hajléktalanság.

A szegénység és esélytelenség nem csak abszolút értelemben vett probléma. Az egyes emberek és a társadalom szempontjából nem kevésbé fontos a különbségek növekedése. Nem véletlenül szerepel tehát elsóként a sorban a társadalmi egyenlőtlenségek felerôsödése, ami ebben az értelmezésben oka is, nem csak következménye a szegénységnek.

A probléma jelentőségére utal az is, hogy a felnôttéletre készülóknek nemcsak a szegénység okaival kellett tisztában lenniük, de tudniuk kellett megnevezni tíz (!) olyan erốforrást is, amelyeknek az elosztásában mutatkozó különbségek társadalmi egyenlótlenségek kialakulásához vezetnek. A tananyag itt a következóket fogadja el helyes válaszként:

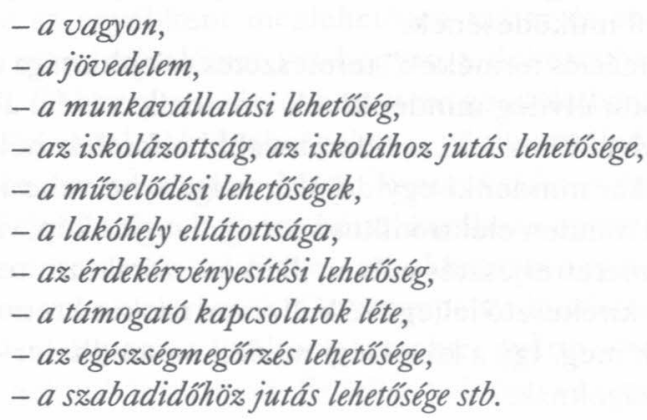


Az információs társadalom szempontjából tekintve a kérdést, elsố reakcióként természetesen megjegyezhetném, hogy a sorban elókelő helyen szerepeltetni kellene az információhoz jutás lehetôségét is. (Ha már a tankönyv is „lehetőségeket” említ, egyértelmúvé téve, hogy az eltérô lehetôségek, vagyis az eltérố esélyek azok, amik a nemkívánatos különbségekhez vezetnek.) Ez alkalommal azonban nem kizárólag az információ fontosságára kívánom felhívni a figyelmet.

Az információs társadalom jelenségeit - ha tetszik, magát az információs társadalmat most abból a szempontból kívánom vizsgálni, hogy a fent vázolt igen fontos társadalmi problémára miként kínál megoldást. Amikor információs társadalomról beszélünk, az emberi társadalomnak és a gazdaságnak azt a változását emeljük ki, melynek során az információ meghatározó „,eróforrássá” válik. Ez az infokommunikációs technológia széles körú terjedése nyomán történik, amikor egyre több termék és szolgáltatás elektronizálódik és digitalizálódik, s eközben immateriálissá, azaz „információvá”, a számítógép mint meghatározó eszköz által feldolgozható adattá válik. Innen az információs társadalom elnevezés.

Ez az átváltozás analógiát mutat azzal a folyamattal, amely az ipari társadalom fejlődése során játszódott le, $s$ amelynek eredményeként egyre több termék és szolgáltatás vált „áruvá”, azaz a piac mint meghatározó gazdasági modell által kezelhetô ,jószággá". A piaci áruk jellemzố meghatározója a kirekesztố és a versengố tulajdonság. A piaci modell múködésének lényege az ezeken a tulajdonságokon alapuló verseny. Ezek a tulajdonságok szükségesek a verseny-piac hatékony múködéséhez.

Napjainkban tanúi vagyunk egyfelól a „piac kudarcainak” (az egyik ilyen kudarc éppen a meglehetôsen negatív externáliának tekinthető társadalmi különbségek megléte), másfelól azoknak a törekvéseknek, amelyek megpróbálnak mindent, így az információt is piaci áruként kezelni.

Az információs társadalom fejlődésének a termékek és szolgáltatások „információvá válásán" kívül van egy másik érdekes jelensége is. Ez pedig az információnak (az információs terméknek) a piaci termelési modelltól különböző, jellemzően közösségi modellben történő előállítása és az ahhoz való hozzáférés biztosítása. A közösségi modell elnevezést az indokolja, hogy ebben a modellben a piac termelói, kínálati oldalának szereplői sok esetben nem versenyeznek, hanem együttmúködnek (a verseny - ha van - nem piaci verseny, nem árverseny, sokkal inkább: sport). A fók különbséget a kínálati és a keresleti (termelói és fogyasztói) oldal közötti viszony jelenti, tekintve, hogy nincs alku, és nincs piaci ár sem. Az ilyen modellek terjedését az információnak - mármint a számítógép által feldolgozható adatnak - az a sajátos jellege teszi lehetôvé, hogy nem korlátos erőforrás. Ez egyben a nem versengô, nem kirekesztô tulajdonságok magyarázata is, ami nem kedvez a piaci modell múködésének.

Az „információk” vagy az „információs termékek” természetes tulajdonsága tehát az, hogy ha egyszer már léteznek, akkor elvileg mindenkinek a rendelkezésére állnak (tekintve, hogy végtelen sok példányban léteznek, minden további ráfordítás nélkül). Ezért mindenkinek juthat belólük, akár mindenki egyidejúleg is igénybe veheti azokat. Ilyen információs termék például minden elektronikus szöveg, hang és kép, vagyis a kultúra és a tudomány, a tudás- és ismeretterjesztés múvei, illetve a szórakozás termékei. Ahhoz, hogy piaci áruvá váljanak, kirekesztố jellegúvé kell tenni ezeket a termékeket, ami ma a jog eszközeivel történik meg. Így a közösségi modell - mondhatni - természetesebb környezete az ilyen jószágoknak. 
Hasonló tulajdonságúak és hasonlóan viselkednek a számítógépben használatos szoftverek is. Nem véletlen tehát, hogy a szoftverek elóállításával összefüggésben alakultak ki az első „információs kori” közösségi modellek - ismertebb nevükön a nyílt és szabad szoftverekról van szó. A legismertebbek hátterében általában egy-egy projekt áll, amelyben több tucat fejlesztô dolgozik, nem ritkán több száz önkéntes segítô közremúködésével. A projektek finanszírozását általában valamilyen alapítvány biztosítja, a pénzügyi alapokat adományok, szponzorok, pályázati pénzek jelentik. Az ilyen módon közösségi forrásokból keletkező programok teljes mértékben közös jószággá válnak, mindenki által elérhetôek, hiszen - ha már egyszer elkészültek - végtelen sok példányukból mindenkinek jut.

Az esélyek egyenlőtlenségéról így ír Ladányi János: „A szegénységnek egy olyan formájáról van szó, amely nem egyszerúen alacsonyabb jövedelmet, rosszabb lakáskörülményeket, alacsonyabb életszínvonalat stb. jelent. Hanem mindenekelốtt azt, hogy Magyarországon megjelenik egy olyan, a társadalom többségétól élesen elkülönülő, tartósan leszakadó társadalmi réteg, amelynek a jelenlegi tendenciák folytatódása esetén nincs esélye arra, hogy bekapcsolódjék a munkamegosztás kialakulófélben levơ uij rendszerébe, hogy „normális” munkája, jövedelme, lakása, társadalombiztositása legyen, hogy gyerekeit megfelelóen tudja iskoláztatni."

Hasonlóképpen fogalmaz - sốt újabb területeket nevez meg - az Európai Bizottság egyik közleménye is, arra hívva fel a figyelmet, hogy a társadalmi kohéziót gyengítő társadalmi kirekesztốdés (a társadalom többségétól való éles elkülönülés) multidimenzionális jelenség, amely magában foglalja a munkaerópiacon való érvényesüléssel, az oktatással, a* egészségügyi ellátással, a igazságszolgáltatással, az állampolgári jogokkal és a döntéshozatalban való részvétellel kapcsolatos problémákat.

Az immaterializálódás, az információs termékké válás folyamata nyilvánvalóan nem jelenthet megoldást minden problémára, különösen az olyan alapvetố materiális szükségletek esetében nem, amilyen például a lakás, az étkezés, a ruházkodás. Az információs társadalom fejlódése ugyanakkor a felsoroltak közül többnek az esetében is jelentôsen átrendezheti a jobb, illetve rosszabb esélyekkel rendelkezók körét. Ehhez az átrendeződéshez maga a közösségi modellben végzett termék-elóállítás, az ennek a sajátosságai miatt átalakuló társadalmi munkamegosztás és az információs termékekhez történó újfajta (közösségi) hozzáférési formák egyaránt hozzájárulhatnak.

Ezzel a témával eredetileg egy konferencián tartott elöadásban foglalkoztam. Az előadásra készülve felvetődött bennem az a gondolat, hogy jó lenne az egyébként meglehetősen száraz és elvont mondanivalómat valahogyan érdekesebbé tenni. Ehhez olyan témát kerestem gondolatban, ami a társadalmi különbségeket is jól illusztrálná. Ekkor jutott eszembe Mark Twain Koldus és királyfi címú múve. Néhány héttel korábban ugyan-

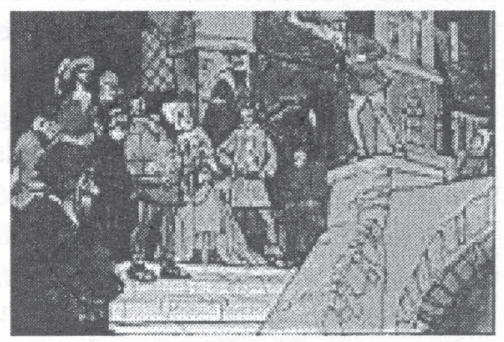
is - az interneten szörfözve - rábukkantam egy honlapra, ahol diafilmek digitalizált változatai voltak elérhetốk. Ott szerepelt a kínálatban a Gulliver Lilliputban címú diafilm, ráadásul éppen az a változat, amelyet gyermekkoromban sokat nézhettem otthon, hiszen nekünk is megvolt. Érdekes volt újra végignézni a rég nem látott, de emlékezetes 
képeket. Az is eszembe jutott, hogy az otthoni gyưjteményben szerepelt a Koldus és királyfi is. Elkezdtem tehát keresni ezt a diafilmet, gondolván, hogy majd abból kivágok néhány érdekes kockát.

Hamarosan az alábbi nyitóoldalon találtam magam:

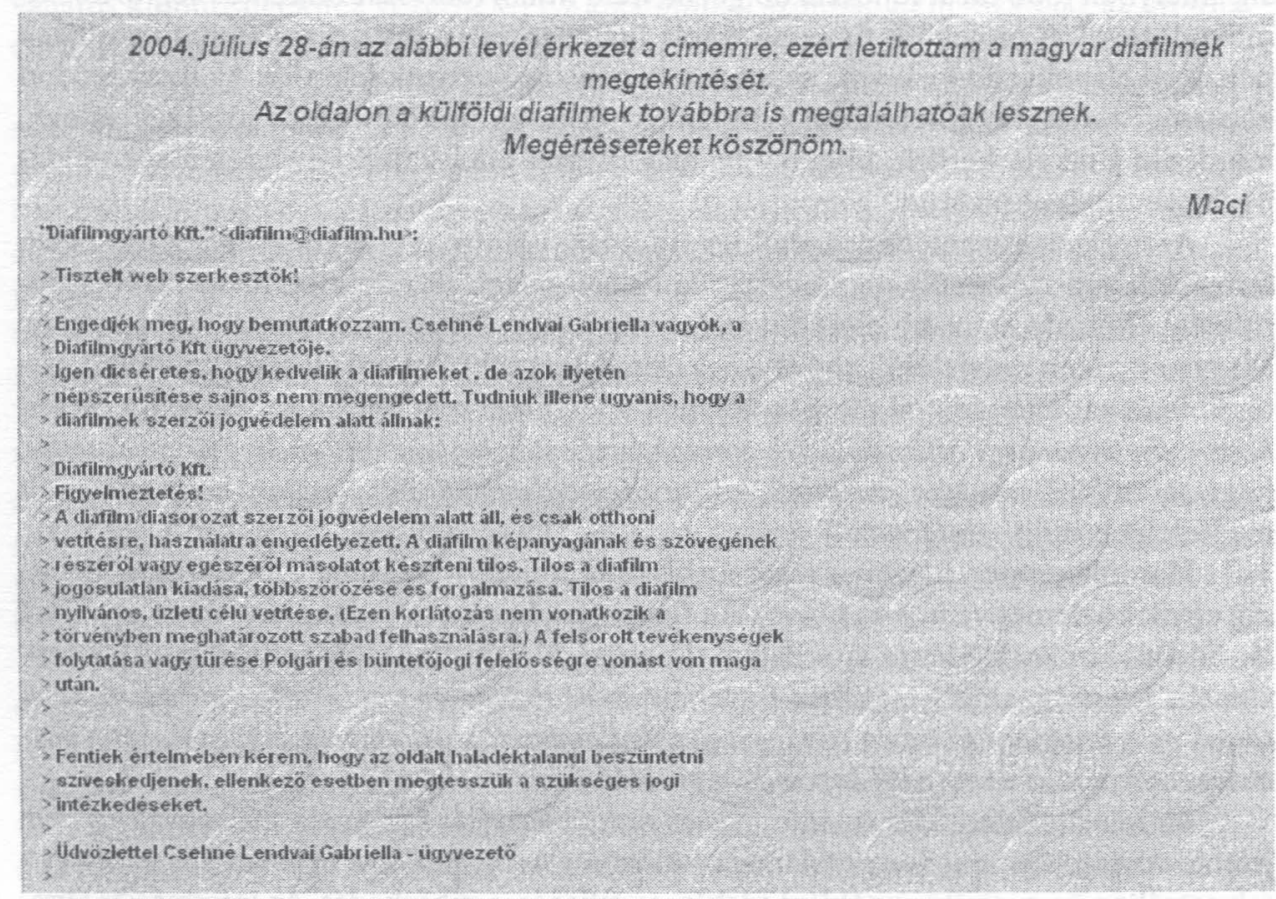

Ez tehát nem volt más, mint ami a piaci modell „normál” múködéséhez szükséges, a jog által kirekesztốvé tétel bizonyítéka (ténye). Teljes mértékben érthetô, hiszen a Diafilmgyártó Kft. és annak ügyvezetôje is a „piacról él”. Ha mindenki „csak úgy”, ingyen letölthetné a diafilmeket, akkor ók becsukhatnák a boltot. Persze feltehető volna a kérdés ilyen formában is: Mi a fontosabb? Az, hogy a Diafilmgyártó Kft. létezzen, és az ott dolgozó néhány ember megéljen, vagy az, hogy minél többen megismerhessék a világirodalom remekmúveit? Nyilván mind a kettô. Úgy tűnik azonban, hogy a piaci modell ezt a kérdést nehezen tudja így kezelni.

Kíváncsi lettem, mekkora üzlet a diafilmgyártás. A Koldus és királyfit a cég $700 \mathrm{Ft}$-ért kínálja. A hozzáférhetố cégadatokból az derül ki, hogy egy-egy filmból átlagosan 500 db-ot értékesítenek. Ha tehát feltételezzük, hogy az eladási ár fele a cég és a dolgozók megélhetését szolgálja, akkor a Koldus és királyfi kb. 175 ezer Ft-tal járul ehhez hozzá, miközben 500 család lett jogosult a diafilm megtekintésére. Ennél nyilvánvalóan nagyságrenddel kisebb összegból megoldható lenne, hogy akár minden gyerek megnézhesse a szórakoztató filmet!

A piaci modellhez még az is hozzátartozik, hogy az a pár száz vevô, aki egy-egy évben megveszi a filmet, nem ennyit fizet érte. A kiskereskedelemben ugyanez a film 990 és 3800 (!) Ft közötti áron vásárolható meg, legalábbis az interneten elérhetố árjegyzékek tanúsága szerint. 


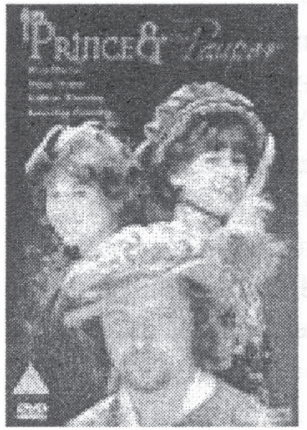

A diafilm persze manapság nem olyan divatos, mint az én gyermekkoromban, amikor a tv-korszak még éppen csak elkezdốdött, a mozgóképvetítés otthoni körülmények között ritkaságszámba ment. A technika fejlődésével a világhírü múalkotások is új hordozókon jelentek meg. A Koldus és királyfíból film is készült, amelyet természetesen meg is lehet vásárolni - manapság már fóleg DVD-n. A világhálón keresztül akár meg is rendelhetô, 1000 Ft körüli áron (ami - öszszehasonlítva a diafilm árával - nem is magas). Sốt, a kultúra kommercializálódásának bizonyítékaként ennél még olcsóbban is, ha a Mark Twain múve alapján 2000-ben készült film mellé a Hegylakó második részét is megvásároljuk.

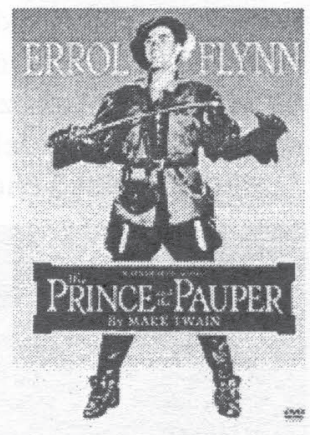

A világháló éppen olyan globális, mint a piacgazdaság, így ma már a magyar vásárlók számára sem kizárólag a magyarországi kínálat elérhető. Aki meg tudja fizetni, válogathat a világpiac kínálatából, ahol akár az 1937-ben Errol Flynn fôszereplésével készült film digitális változata is megvásárolható 9 és 18 dollár (kb. 1800-3600 Ft) közötti áron.

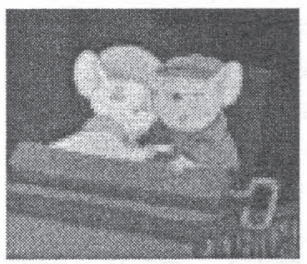

Követve a divat változásait, alkalmazkodva a vásárlók igényeihez és ízléséhez (vagy irányítva azt), a „Koldus és királyfi” - eredeti címén: „The Prince and the Pauper" - számos feldolgozásban jelent meg. Ezek közül a legérdekesebb talán a rajzfilmes változat. A Mickey Mouse-os változatnak, amely 1977-ben készült, és a késóbbi 1990-es feldolgozásnak magyar vonatkozása is van: Biankának Gábor Zsazsa húga, Gábor Éva

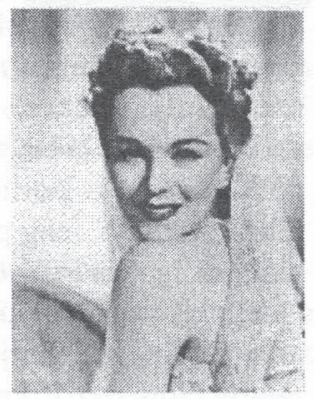
kölcsönzi a hangját.

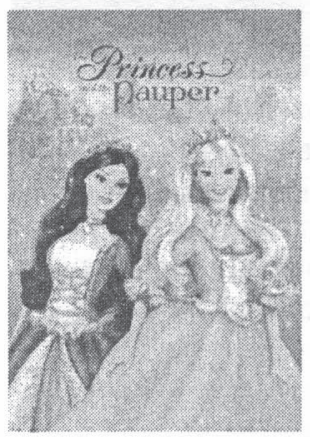

A legújabb kori feldolgozások kapcsán természetesen felvetôdik a kérdés, hogy mennyi közük van az eredeti alkotáshoz, mennyiben tekinthetốk kultúra-közvetítônek és mennyiben egyszerú piaci árunak, az eredeti történet azonban - úgy tû́nik piacképes. Amikor az egymáshoz megszólalásig hasonlító, de a társadalom két különbözố rétegéból származó, eltérô neveltetésú és tudású és ennek megfelelôen teljesen különbözố esélyekkel és lehetőségekkel rendelkezô ember egy rövid idôre szerepet cserél, izgalmas helyzetek alakulnak ki.

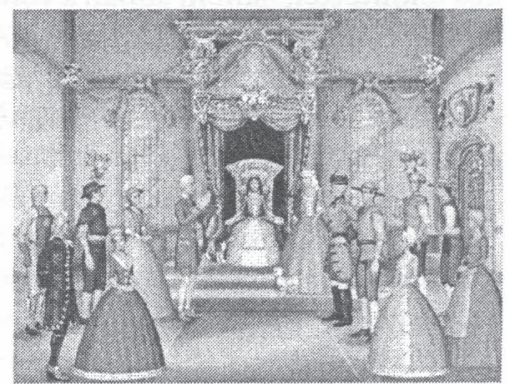


Az pedig már csak a gyártók tól és a kereskedóktól függ, hogy milyen köntösbe bújtatják a szereplóket az eladhatóság érdekében. Így születhetett a könyvból Barbie-stílusú gyerekkönyv, CD-ROM, sốt videojáték.

A piaci árak e termékek esetében is 10 és 20 dollár között mozognak (kb. $2000-4000 \mathrm{Ft}$ ). Minden bizonnyal a magas árak is szerepet játszottak abban, hogy a video- és DVD-termékek esetében kialakult egyfajta közösségi modell, a közös fogyasztás modellje. Mivel ezeket a filmeket (?) az emberek általában nem túl sokszor nézik meg, nem igénylik feltétlenül, hogy a mú saját tulajdonukban legyen, takarékos megoldásként igénybe vehetik a kölcsönzési szolgáltatást.

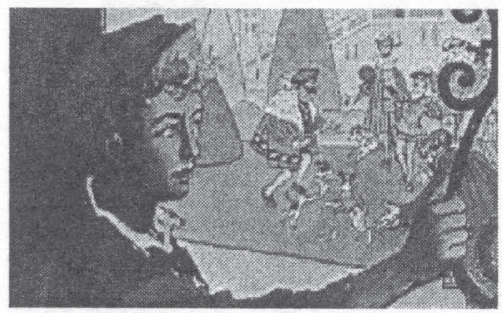

Diafilmek esetében is létezik ez a lehetôség, mint ahogyan videók és DVD-k is kölcsönözhetók. Ez a fajta szolgáltatás két hasonló modellben múködtethetô, és a valóságban mindkét modell, sốt a kettố kombinációja is létezik. Az elsố a tiszta klubmodell. Ebbe a klubba belépók tagsági díjat fizetnek, az így összegyúlt pénzból a klub megvásárolja a piaci terméket, és további díjfizetés nélkül tagjai rendelkezésére bocsátja azt. A Koldus és királyfi például az általam is ismert diafilmen hozzáférhetố évi $2000 \mathrm{Ft}$-os tagsági díjért, amiért persze sok-sok további dia is megnézhető. A másik a tiszta használatalapú modell. Ebben a modellben egy vállalkozó (vagy nonprofit szervezet, mindkettốre van példa) megvásárolja a filmeket (diafilmeket), megbecsüli, hogy egy-egy példányt hányszor tud bérbe adni, s ennek alapján - gyakorlatilag a piaci modellt követve - kiszámítja az egy felhasználóra jutó díjat. Ez a félig közösségi, félig piaci modell múködik például az on-demand videoszolgáltatások esetében, amikor gyakorlatilag házimozi jelleggel, vetítésenként fizetünk. Így már akár 1,99 dollárért (400 Ft) megnézhetjük a 2000-ben készült The Prince and the Pauper címú mozifilm videováltozatát. A két modell kombinációjaként múködik a kölcsönzói modell. Nálunk például évi 2000 Ft-os éves tagsági díjat és ezenkívül alkalmanként $530 \mathrm{Ft}$-ot kell fizetni, ha meg akarjuk nézni a Koldus és királyfit.

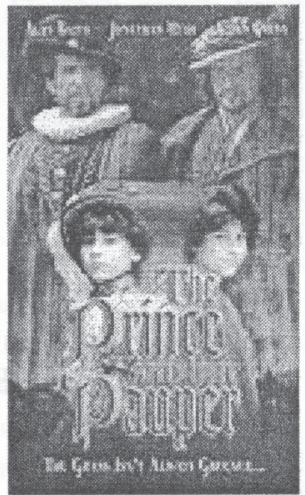

Ekkor már nemcsak abban a vonatkozásban kezdett foglalkoztatni a kérdés, hogy sikerül-e megtalálnom az általam „eredetinek” tekintett diafilmet, a tiltásra való különös tekintettel, hanem abban a vonatkozásban is, hogy az információs társadalom ,gyermekei”, amikor majd a Koldus és királyfi történetéról lesz szó, vajon kizárólag Miki egérre, Barbie-ra, esetleg Gábor Évára asszociálnak-e, vagy ismerni fogják Mark Twain eredeti múvét is? A kutatás során valódi közös jószágként múködő nyilvános archivumokat, könyvtárakat találtam. 
Magyarországon talán a legismertebb a Széchényi könyvtár által üzemeltetett Magyar Elektronikus Könyvtár (MEK, http://mek.oszk.hu/00500/00530). Természetesen (vagy szerencsére?) ebben megtalálható elektronikus formában ez a mú, és Jékely Zoltán fordításában online elolvasható HTML-, Word-, RTF- vagy PDF-formátumban, akár le is tölthető ezekben változatokban, sốt, a könyvtár egyik speciális szolgáltatásaként meg is hallgatható, mivel a szöveget a számítógép kérésünkre fel is olvassa. Az eredeti mú angolul is megtalálható és bárki által hozzáférhetố pl. az amerikai irodalom klasszikusainak múveit tartalmazó közgyújiteményben (http://www.americanliterature.com/PP/PPINDX.HTML), de több közösségi modellben megvalósított projekt létezik, amelyek célja hasonló: a világirodalom értékes alkotásainak közkinccsé tétele (http://www.onlineliterature.com/twain/princepauper/ http://www.pagebypagebooks. com/Mark_Twain/The_Prince_and_the_Pauper/index.html). Ezek közül - legalábbis egyelốre - a legnagyobb a Gutenberg-projekt, amelynek keretében eddig 17000 múvet tettek elérhetôvé mindenki számára. A letöltés itt a "hagyományos” internet- (http, ftp) csatornák mellett a magnetlinks (P2P) hálózat útján is lehetséges - a tényleges letöltések száma több mint
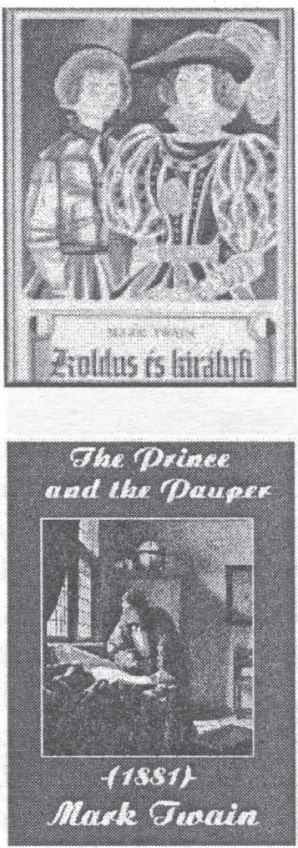
2 millió könyv havonta. Ebben a valódi közösségi modell szerint múködố projektben több száz önkéntes múködik együtt. Mark Twain a statisztikák szerint az egyik legnépszerúbb író, naponta több mint 1500, hetente több mint tízezer példányt töltenek le múveibó1, köztük a The Prince and the Paupert (http://www.gutenberg.org/etext/1837), ami 2004. júliusa óta érhetô itt el.

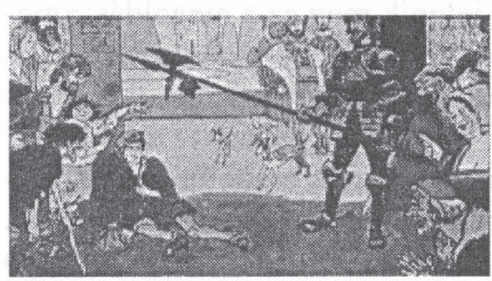

Az eredetileg pusztán illusztrációnak szánt ötlet alapját, az 1958-ban Zórád Ernő rajzaival készült diafilmet egészében ugyan nem, de abból három kockát végül is sikerült elérnem a weben, a Diafilmgyártó Kft.-nél (http://www.diafilm.hu/311.html), közben azonban sikerült olyan értékes - részben közkinccsé tett - magángyújteményt találnom, amely mintaértékú lehet (http://www.diafilmmuzeum.hu). A honlapról 2003. augusztus 14-én a Magyar Hírlap Online ezt írta:

Bíró Ferenc több mint 4500 darabos diagyújteményének egy része másfél hónapja a www.diafilmmúzeum.hu internetes weblapon megtekinthető. Bíró Ferenc - aki civilben a VI. kerületi önkormányzat oktatási irodájának vezetố fớtanácsosa - a hetvenes években szintén szakdolgozati témaként találkozott először a diafilmmel. Régi vágya volt egy diamúzeum létrehozása, és egyeloore ez virtuálisan sikerült. Jelenleg a gyưjtemény darabjaiból az 1926-tól 1956-ig megjelenteket lehet levetíteni az interneten. Közülük több, fóként az ötvenes években kiadottak, politikai megrendelésre készült. A tervek szerint hamarosan bốvül a virtuális múzeum anyaga, és húsz. 1954 és 1962 között készült, diára fotografált színes tájfilmsorozat is látható lesz. 


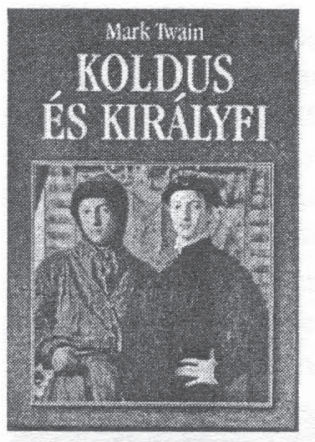

A közösségi modell valósul meg egy másik - a Gutenberg-projekthez hasonló - formában a Wikipedia oldalain. Ez a projekt egy olyan online lexikont, ismeret- és tudásbázist hozott létre, amelyhez mindenki egyenlő eséllyel hozzáférhet, sôt annak szerkesztő́je is lehet. Az eredeti, angol nyelvú projekt 2001 januárjában indult, akkor még egy kis internetes cég kezdeményezéseként. Az angol enciklopédia 2005 végén 900 000-nél több címszót tartalmazott. Az elmúlt években számos nemzeti változat is útjára indult, köztük a magyar Wikipédia is, A szócikkek száma meghaladja a 2,2 milliót. Természetesen a Koldus és királyfi, illetve a The Prince and the Pauper kimerítố ismertetése is megtalálható itt. A Wikipedia mintájára az elmúlt években több hasonló wiki indult, amelyeknek közös jellemzóje a közösségi termelési modell, vagyis a tartalmat a közösség (bárki) állítja elô, és a közösségi fogyasztási modell, vagyis nyílt tartalmúak és a GNU GPL (szabaddokumentáció-licenc, vagy „copyleft”) szerzối jogi szabályai vonatkoznak rá.

A projektek hátterében ma a Wikimedia Alapituány áll, az a szervezet, amelyik a Wikipédiát és annak testvérprojektjeit (Wiktionary, Wikiquote, Wikibooks, Wikisource, Wikimedia Commons, In Memoriam 9/11 és Nupedia) üzemelteti és fejleszti. Az alapítvány egy nonprofit szervezet, amelyet Florida (USA) jogterületén jegyeztek be. Létrejöttét hivatalosan Jimbo Wales, a Bomis cég vezetốje és a Wikipedia társalapítója jelentette be 2003. június 20-án. A wiki projekteket - többek között - támogatja Richard Stallman, a szabadszoftver-mozgalom és a Szabad Szoftver Alapítvány (Free Software Foundation, FSF) ismert egyénisége, a GNU GPL kidolgozója.

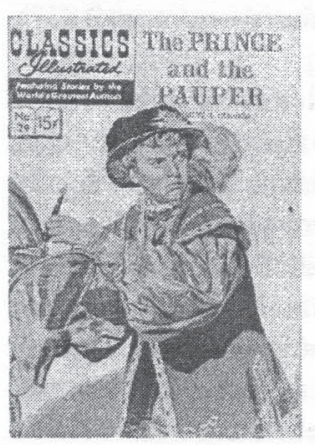

Ugyancsak a Gutenberg projekt kapcsán megemlítendó jelenség a peer-to-peer (P2P) hálózatok kialakulása. Ott ugyan csak technológiai kérdésként jelenik meg ez a megoldás, amelyet azért alkalmaznak, mert nagy médiafájlok letöltésére a hagyományos internetprotokollok nem elég hatékonyak. A P2Phálózatok kialakulása azonban tartalmi kérdésnek is tekinthetó. Ha nem is a tartalom-elóállítás kollektív modelljét jelentik legalábbis nem abban az értelemben, hogy az egyes múvek közösségi formában jönnek létre -, de az információk (fájlok) mindenképpen közös tulajdonként, a közösség közös tartalomszolgáltatóként múködik. Márpedig nagyon sok minden elérhetô. Olyan múvek, alkotások is, amelyek máshol meg sem találhatók. A Koldus és királyfi olyan képregényváltozataihoz, különféle kiadásainak fakszimile változataihoz sikerült az egyik ilyen hálózatban (eD2K) hozzájutnom, amelyeknek más csatornákon nyoma sem volt. Rengeteg dokumentum (szöveg, hang, kép, adatbázis, egyszóval minden, ami digitalizálható) megtalálható ebben a hálózatban, amelyben egyidejúleg 4-5 millió felhasználó van jelen, akiknek a háttértárain összesen 4-500 millió fájl érhető el. A tartalmak általában egyéni munkával (grabbelés, szkennelés,

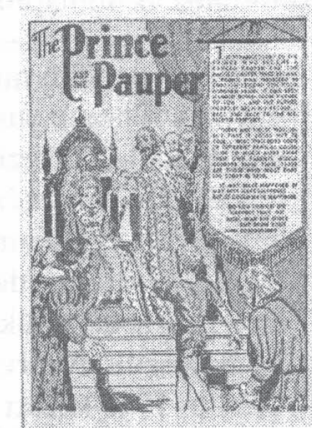


fotózás, gépelés stb.) jönnek létre - kétségtelen, hogy sok esetben megkérdôjelezhetô szerzói jogi körülmények között.

A közösségi modellre egy új, szerzói jogi szempontból is minden bizonnyal problémamentes és a múvek hozzáférhetôségét mindenki számára azonos eséllyel biztosító megoldás az, ami a Sulinet honlapon található felhívás nyomán kirajzolódik. S micsoda véletlen! A Koldus és királyfi is a meghirdetett múvek között szerepel. Kár, hogy a beküldési határidő csak hónapok múlva telik le. Pedig milyen jó illusztráció lehetett volna az esélyegyenlőséget szolgáló közösségi modelleket bemutató prezentációban...

Új pályázatunk azoknak a kreativ, jó rajzkészségü általános és középiskolásoknak szól, akik mindemellett még a szépirodalmat is kedvelik. A kitüzött feladat: Készits képregényt az iskolai kötelezó olvasmányok valamelyikéból!

Pályázhatnak: általános iskolások és középiskolások

A pályázat témája: a kötelezố irodalmak közül egy tetszólegesen választott regény, eposz, novella vagy verses elbeszélés képregényes változatának elkészítése Határidő: 2006. április 30.

Nyeremények: A legjobban sikerült képregényeknek a Sulinet honlapján internetes megjelenést biztosítunk. További nyeremények: könyvek, valamint késóbb meghatározott egyéb nyeremények.

Néhány példa a kötelezók közül:

...Tamási Áron: Ábel a rengetegben; Twain: Koldus és királyfi; Móricz: Légy jó mindhalálig... 